\title{
DESIGNING ENGLISH SYLLABUS FOR KINDERGARTEN AT TK NISRINA BEKASI
}

\author{
$1^{\text {st }}$ Ika Chairiyani \\ English Education Department \\ STKIP Panca Sakti, Jawa Barat, Indonesia \\ Ikachairiyani189@gmail.com
}

\author{
$2^{\text {nd }}$ Rahmat \\ Akademi Maritim Pembangunan, \\ Ketatalaksanaan Pelayaran Niaga, Indonesia \\ Rahmats.164@gmail.com
}

\begin{abstract}
The syllabus is developed based on the curriculum which is made after carrying out the need analysis. The draft of the syllabus was evaluated by two experts and the feedbacks were used to revise the draft. Field try-out was conducted to get feedbacks used to revise the draft. The final revision is the Final Product. The instruments used to collect the data were questionnaires, observation, and interview. The results of needs analysis showed that the teachers got confused to formulate learning objectives. They also had difficulties to find the materials for several themes and sub-themes and they only applied a few teaching techniques and very limited media. This occurs because there is no curriculum for teaching English in kindergarten. Therefore, from the data, the first draft of syllabus was made. Then it was revised after obtaining the feedback from the experts. Moreover, the materials are designed and developed based on the students' needs. Then, the syllabus and materials are ready to be delivered to students at TK Nisrina Bekasi.
\end{abstract}

Keywords: curriculum; syllabus; need analysis; students' needs; instrument

\section{INTRODUCTION}

Teaching foreign language for young learners is now widely discussed in Indonesia. This because many people realize that learning a foreign language will be beneficial if it is started in the early years. Therefore, there are so many preschools and primary schools which offer the English program for their students.

Language and thought are central to learning. Children develop their communicative skill through social interaction that allows them to have numerous experiences which lead them in thinking and talking in English. While they communicate in English, they learn a set of code in English.

Many experts notice the advantages of offering the English program such as helping children to acquire the foreign language starting from the early years, helping them to improve their cognitive development using the language, and offering a great chance for children to improve the listening comprehension which leads them to have a native-like pronunciation (Cameron, 2009).

Teaching foreign languages to young children requires an understanding of theoretical knowledge which can help the process of teaching and learning. The theory of teaching young learners has an important role in working with children and thus it increases the quality of foreign language teaching. Also, it avoids misunderstanding or misleading teaching foreign language to children. Some misunderstandings of teaching young learners are teaching children is straightforward, and children only need to learn a simple language.

Although children view the world 
less complicated than adults do, but it doesn't mean those teaching children are simple and straightforward. It makes a high demand for teachers to be highly skilled to reach the children's world, and they have to understand how children learn. Moreover, children learn the language from the simple to the complex words. They are interested in topics that are complicated such as dinosaurs (Cameron, 2009).

Considering how important teaching English as a foreign language from the early years, the writer intends to design the English curriculum with the English syllabus for her pre-school. She tries to prove any theories related to teaching young learners. Besides, there is a great demand from parents whose children learn in her institution to have an English class as a part of the teaching and learning process. Of course, this demand challenges her, and she tries to make it come true by carrying out this research.

Based on the preliminary research, this study develops An English Syllabus Design for Kindergarten Nisrina. The Kindergarten Nisrina was chosen for some reasons, namely; the preschool is well developed and well-known in its area. Well-developed means that under three years it has significant growth. For the first time, this school had only Kindergarten (TK A), but then, TK B, Preschool, and Full day Care.

Besides, the writer choses it because this school won the competition about the Best Day Care Se-Jawa Barat. Then, the increasing needs from parents having an English program at this institution encourage me to design the English program which can be implemented. Most parents want their children to be able to speak or at least can get in touch with English because most elementary schools near TK Nisrina use English as a medium of instruction.
The problem can be identified as the non-existence of the English syllabus at this school. Moreover, it is contradictory to the needs of parents and students toward English as a preparation for primary school.

Besides that, teachers did not know the strategies on teaching English for young learners, and how to enrich English exposure to young learners. It can be concluded that in this school, teachers need the English syllabus model which covers the goals, indicators, materials, teaching techniques, and evaluation to assist them in teaching English.

Early year education should allow students to develop students' knowledge and cognitive development. Thus, the learning situation should be set comprehensively with the program which suits the vision and mission of this school. Then, the learning situation should give students a chance to explore anything about life and things around them; therefore, students can develop their language skills.

Learning English is the same as learning other languages. It takes time, enjoyable classroom, challenging and fun activities, etc. Nevertheless, teaching English to young learners helps them to acquire the language easily because children's brains can absorb the language much easier than adults do.

The research related to designing the English syllabus has been carried out by some researchers. The result of their study is that designing the syllabus needs some preliminary steps that anyone should follow. First, need analysis for the objects of the research or from informants is a must. Second, analyzing the result of the need analysis is also important to know students' strengths and weaknesses in learning a foreign language. Then, formulating the objective and breaking down into goals are the steps before 
designing materials and methods in teaching English for young learners. Wardono (2010) from UNIKA Atmajaya already researched his dissertation related to the English syllabus model for primary school. This research also carried out the needs analysis to get the real data from the respondents or object of the research.

The instrument of her research was interviews, observation, and questionnaires. The result of her study is that the readymade syllabus model for primary school (Wardono, 2010). He also carried out the research related to design a task-based syllabus for primary school. She followed the stages of designing a syllabus such as needs analysis, formulating objectives, etc. Here, the writer attempts her interest in preschool years and tries to design the English syllabus model for kindergarten.

View of what language is or what being proficient in a language affects what teachers taught and how they teach it. Beliefs about the view of language should be emphasized will translate into beliefs about how language should be learned. An emphasis on language as rule-governed may translate into the belief that learning a language means learning to use it accurately. An emphasis on language as meaning-based may be manifest in the belief that language in the classroom should be relevant and meaningful to the students in the class. Then, an emphasis on language as socially constructed among language requires an awareness of how language is used given in the community.

The fundamental issue around learning is the view of how people learn and the roles of teachers to make them learn. The learner is viewed as a maker of knowledge. Then, learning can be viewed as the process of applying received knowledge. The learners are viewed as an internalizes of knowledge, while learning can be viewed as a cognitive process, involving mental activity, an effective process, emotional connection and risktaking, and a social process (Graves, 2000). Beliefs about teaching also influence the teachers' methodology in language teaching. Beliefs about teaching and the role of teachers are related to beliefs about learning. The process of teaching can be viewed that the teacher transmits the knowledge to the students.

These views affect teachers in teaching English in the classroom and affect them in designing syllabus and materials. View about how children learn a foreign language also affects teachers in considering and choosing the learnable materials, applicable method of teaching, and enjoyable situation in class. The followings are what experts say about how young learners learn a foreign language.

Dudley-Evan and St. John (1998) state that Needs analysis must try to find out the following information; (1) professional information about the learners. (2) Personal information about learners, (3) English Language Information, what their current skills and language use are, (4) the learners' lacks, (5) language learning information: effective ways of learning the skills and the language, (6) professional communication information, (7) what is wanted from the course, (8) information about the environment in which the course will be run.

The process of needs assessment or needs analysis involves a set of decisions, actions, and reflections (Graves, 2000). The followings are the lists of the process;

1. Deciding what information to gather and why

2. Deciding the best way to gather it, when, how and from whom

3. Gathering information

4. Interpreting the information

5. Acting on the information 
Dialectical Literature and Education Journal (DLEJ) Volume 5, Issue 1, June 2020

6. Evaluating the effect and the effectiveness of the action

7. Deciding on further or new information to gather

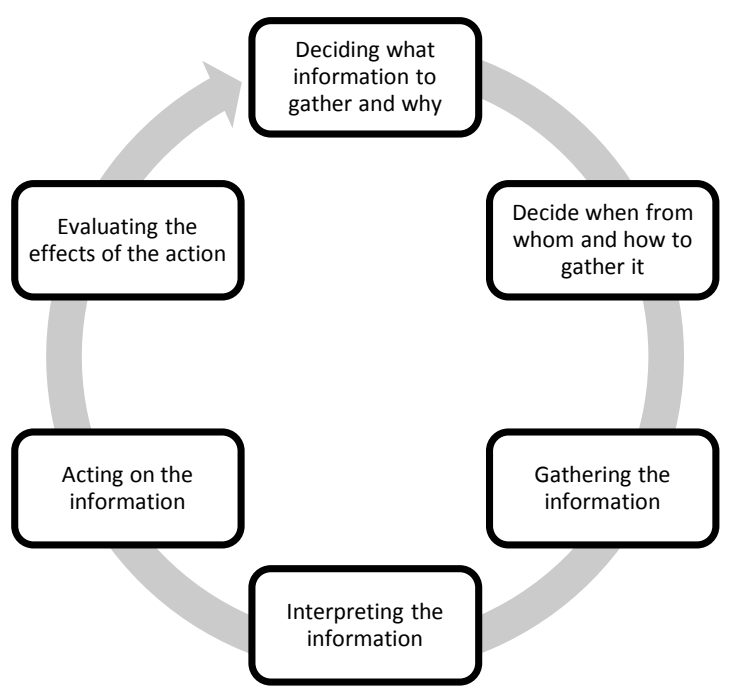

Figure 2.1

\section{Process of Needs Analysis}

Based on "Peraturan Menteri Pendidikan Nasional" (read) Rules of National Education Minister about the Education Standard for Early Childhood Education No. 20 the Year 2003 (Peraturan Menteri Pendidikan Nasional RI Nomor 58 Tahun 2009 tentang Standar Pendidikan Anak Usia Dini, 2009) about the system of Early childhood education is from birth until the age of six in formal and non-formal settings. In the formal setting, it is called Kindergarten (TK)/Raudhatul Athfal (RA), and in the non-formal setting, it is called Full daycare (TPA) ( Peraturan Menteri Pendidikan Nasional Nomor 36 Tahun 2010 tentang Organisasi dan Tata Kerja Kementerian Pendidikan Nasional, 2010).

The role of kindergarten education is to prepare children for the journeyof life long learning. For such a sure start to be realized, a major aim ofkindergarten education is to support and foster the holistic developmentof the child.This involves the nurturing and acceptance of young children'sspontaneous, natural, and varied responses to the wealth and richnessof experiences and opportunities the child is likely to encounter on thelearning journey.Adult and peer support are vital to this process as children extend their skills and knowledge of the world to more elaborate andcomplex ways of learning, doing, and understanding.

Early years education has been perceived by some as a preparation forprimary school. However, it is not just a preparation for the next stage. Itis vitally important in itself. It should not be confused with trying toaccelerate learning in the kindergarten years by providing children witha simplified primary school curriculum.(Stamford American International School, n.d.)

The Beyond Centers and Circle Time is written to offer support to educators and parents who wish to maintain a balance between supporting their child's acquisition of skills and knowledge that will prepare him for later school success and the joys and delights of experiencing a playful childhood.

The research and theory that has guided The BCCT curriculum, used at the Creative Pre-School for over 35 years, provides children with emergent literacy experiences within well planned and implemented play opportunities that use cooking, dramatic play, fluid, and structured construction, and fine and gross motor opportunities to meet the individual and cultural needs of each child while providing him opportunities to develop skills and knowledge in all domains.

This set of themes contains experiences that will support the development of the whole child through topics that young children find interesting. Adults using these themes must be sure that the children know the content being discussed and provide field trips, visitors, books, pictures, and other materials that will give meaning to the topics. The theme 
topics are purposely broad and can be easily extended to last a full month. Children need time to develop knowledge and play skills. The individual interests of the children in the classroom should be used to guide the direction that each theme takes.

BCCT focuses on children and uses four scaffolding to support children in playing while learning. The fourth scaffoldings are setting the playground, scaffolding before play, scaffolding while playing, and scaffolding after play. It can be inferred that the BCCT learning model allows students to learn independently. Teachers' role is a facilitator.

They only facilitate students to learn. Students learn new things through exploration. While they play on the playground, teachers assess students' progress in learning. Therefore, realizing or not, students are learning while they are playing. While teachers set up the playground, they have to consider the followings: a) the activity should be in line with the lesson plan, b) sufficient materials for playing, c) developing students' sensory-motor, cognitive and role play, stimulate students' curiosity, creativity, and activeness, d) considering the density and intensity.

\section{METHOD}

Method Research methodology which is used in this study is Research and Development ( $\mathrm{R} \& \mathrm{D})$. Bennett et al (1984) define the approach of research and development in education is the process to develop and validate an education product.

Sukmadinata (Alexon \& Sukmadinata, 2010) simplified the stages of research and development into three steps such as preliminary study, development, and testing the result preliminary study consists of a literature study and field survey. The development stage consists of writing a preliminary draft, field testing, and the third stage is an experiment to see the effectiveness of the product.

From the tenth steps which are developed by Borg and Gall, only the first step until the seventh step is adapted in this research. It is based on Sukmadinata (Alexon \& Sukmadinata, 2010) that the researcher of the Magister program, the research activity can be stopped until the final draft without testing the result or testing the effectiveness of the product.

Nevertheless, it does not mean that there is no testing; the application of the model is available to create the proper model design.

Based on the objective of the study, this research is a qualitative study. It is designed to identify and describe the learners', teachers', parents', and stakeholders' needs toward English. According to Jack R. Fraenkel and Norman E. Wallen that "Qualitative research is the research in which the investigator attempts to study naturally occurring phenomena in all their complexity".

At the first stage, research and information collecting, the writer has to find the related literature and field study. A literature study is for deriving concepts, and to strengthen the theories. Field study is for assessing needs from the students or participants.

Then, planning includes the objective of the product, who will use the product, and description of the product. 


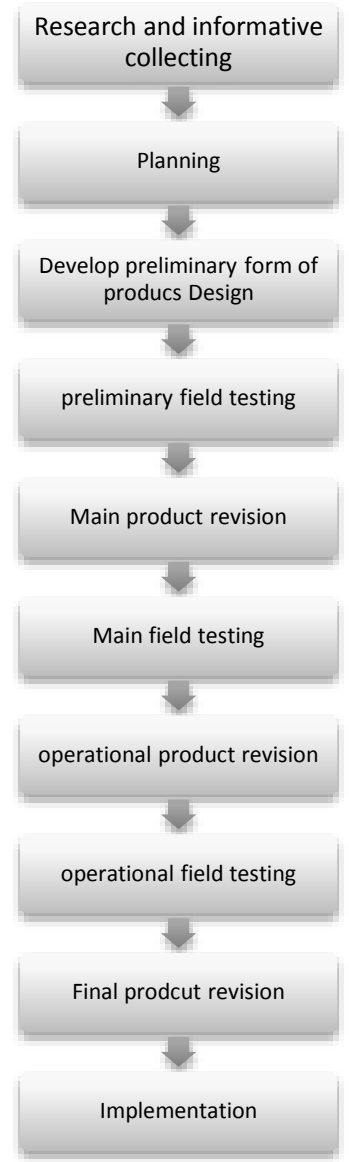

\section{Figure 3.1 Research and Development}

Preliminary field testing means testing the rough draft. After testing the first draft, revision is a must. Then, the revised draft is tested in the next field testing.

\section{RESULTS AND DISCUSSION}

Analysis of Implementing the Syllabus The following is the process of a trial from the first trial until the third trial. The observation not only used for students but also the way the teacher teaches in class. Scoring system for the teacher's presentation as follows;

The above result can be described in graphic design as follows;

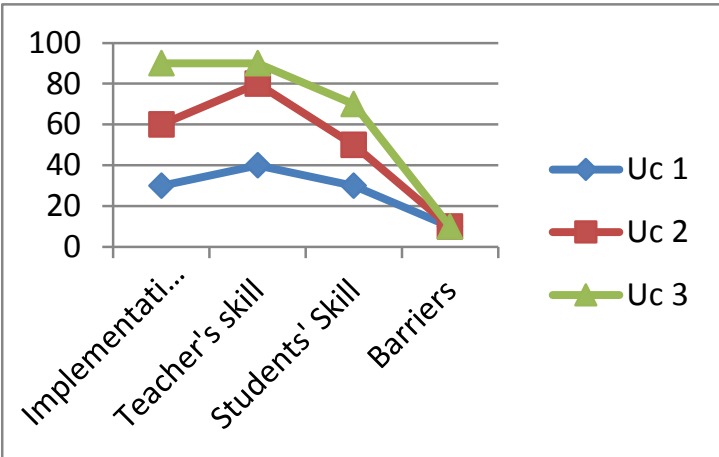

Figure 4.1 Implementation of the syllabus model

From the above chart, it can be seen that teachers and students have progressed in the teaching and learning process. Then, there is progress in each trial. The research design is as follows;

At the first stage, research, and information collecting, the writer has to find the related literature and field study. A literature study is for deriving concepts, and to strengthen the theories. Field study is for assessing needs from the students or participants.

Then, planning includes the objective of the product, who will use the product, and description of the product. Develop preliminary product means to develop a rough draft to be tested in the field study.

Preliminary field testing means testing the rough draft. After testing the first draft, revision is a must. Then, the revised draft is tested in the next field testing.

\section{CONCLUSION}

According to the above data, it can be inferred that there is a significant difference between the first trial, second, 
and third trial. Students' progress in learning English and implementing the syllabus design has significant progress.

Based on the data analysis, it can be summarized that designing the English syllabus model for EFL kindergarten students needs some extensive stages. A preliminary survey called needs analysis, interpreting data from needs analysis, and designing the draft syllabus, consulting with the expert, revising the syllabus, then, implementing (trial), then analyzing the result of the trial. These phases should be followed well.

The response of teachers, parents, and students when the researcher carried out the research (field study) showed how they need English, how they want English to their children, how they expect after learning English for some time.

To design the syllabus, the researcher should put some indicators related to the aspect of development. Therefore, the researcher concluded this syllabus model is called the BCCT model syllabus. This because the syllabus is made based on the learning model implemented to children such as the BCCT learning model. After the syllabus is done, the model should be implemented.

Then, the implementation resulted in significant differences between students' scores from the first trial until the third trial. It indicated some aspects; the teacher is more creative to teach, students are more interested in learning in class, the activity is varied, the task is not too difficult, and teachers can lead students to be independent.

\section{REFERENCES}

Alexon, \& Sukmadinata, N. S. (2010). Pengembangan Model Pembelajaran Terpadu Berbasis Budaya untuk Meningkatkan Apresiasi Siswa terhadap Budaya Lokal. Jurnal
Cakrawala Pendidikan, 2(2), 189203.

https://doi.org/10.21831/cp.v2i2.339

Bennett, N., Borg, W. R., \& Gall, M. D. (1984). Educational Research: An Introduction. British Journal of Educational Studies, 32(1), 1-3. https://doi.org/10.1080/00071005.198 4.9973665

Cameron, L. (2009). Teaching languages to young learners. Cambridge: Cambridge University Press.

Dudley-Evans, T., \& John, M. J. S. (1998). Developments in English for Specific Purposes. A Multi-Disciplinary Approach. Cambridge: Cambridge University Press.

Graves, K. (2000). Designing Language Course: A Guide for Teachers. Boston: Hienle \& Hienle Publishers.

Peraturan Menteri Pendidikan Nasional Nomor 36 Tahun 2010 tentang Organisasi dan Tata Kerja. (2010). Jakarta, Indonesia.

Peraturan Menteri Pendidikan Nasional RI Nomor 58 Tahun 2009 tentang Standar Pendidikan Anak Usia Dini. (2009). Jakarta, Indonesia.

Stamford American International School. (n.d.). Early Childhood Education in Singapore. Diambil 27 Juni 2020, dari https://www.sais.edu.sg/curriculum/e arly-years-

learning/?gclid=Cj0KCQjwudb3BRC 9ARIsAEavUuivZeH95sL64Tg8jb02ZoSuwqq4 -AsQXNWzGxjkjxBTBmhfH62tcaAi3-EALw_wcB

Wardono, H. I. (2010). An English Syllabus Model for Primary School Children: A Study of the Teachers', Parents', and Children's Perspectives on the Needs (Atma Jaya Catholic University). Diambil dari https://lib.atmajaya.ac.id/default.aspx $?$ tabID $=470 \& \mathrm{id}=169473 \&$ lok $=2$ 
Dialectical Literature and Education Journal (DLEJ) Volume 5, Issue 1, June 2020
p-ISSN 2548-6926, e-ISSN 2714-996X

https://dlejpancasakti.ac.id/index.php/dlejpancasakti 


\title{
Appendix
}

\section{DESIGNING ENGLISH SYLLABUS FOR KINDERGARTEN AT TK NISRINA BEKASI}

\author{
SYLLABUS \\ ODD SEMESTER
}

Class : TK B

Objective: Students are able to understand simple vocabulary and to respond simple instruction correctly at fun activities

\begin{tabular}{|c|c|c|c|c|c|}
\hline Theme & $\begin{array}{c}\text { Aspect of } \\
\text { Developmen } \\
\text { t } \\
\end{array}$ & Indicator & $\begin{array}{c}\text { Time } \\
\text { Allotment }\end{array}$ & Materials & Evaluation \\
\hline \multirow[t]{4}{*}{ Parts of Body } & Cognitive & $\begin{array}{l}\partial \text { Mentioning Students' parts of } \\
\text { body correctly } \\
\partial \text { Matching the picture with the } \\
\text { words which describe parts of } \\
\text { body }\end{array}$ & \multirow[t]{4}{*}{3 weeks } & \multirow{4}{*}{$\begin{array}{l}\partial \text { Introducing } \\
\text { parts of body } \\
\partial \text { Drilling parts } \\
\text { of body } \\
\partial \text { Moving } \\
\text { around to find } \\
\text { the words that } \\
\text { describe the } \\
\text { certain parts of } \\
\text { body } \\
\partial \text { Dancing } \\
\text { together to } \\
\text { trigger the } \\
\text { students' } \\
\text { attention } \\
\partial \text { Introducing the } \\
\text { song "Head } \\
\text { and Shoulder" }\end{array}$} & \multirow{4}{*}{$\begin{array}{l}\partial \text { Matching the } \\
\text { picture with the } \\
\text { parts of body } \\
\partial \text { Spelling the } \\
\text { words related to } \\
\text { parts of body the } \\
\partial \text { Writing } \\
\partial \text { words } \\
\partial\end{array}$} \\
\hline & $\begin{array}{l}\text { Language } \\
\text { and Literacy }\end{array}$ & $\begin{array}{l}\partial \text { Writing parts of body correctly } \\
\partial \text { Spelling the words related to the } \\
\text { parts of body well } \\
\partial \text { Responding the simple } \\
\text { instruction related to parts of } \\
\text { body }\end{array}$ & & & \\
\hline & $\begin{array}{l}\text { Socio- } \\
\text { Emotional }\end{array}$ & $\begin{array}{l}\partial \text { Working together with other } \\
\text { friends } \\
\partial \text { Sharing the toys with friends }\end{array}$ & & & \\
\hline & $\begin{array}{l}\text { Motoric/phys } \\
\text { ic }\end{array}$ & $\begin{array}{l}\partial \text { Moving around based on the } \\
\text { instruction } \\
\partial \text { Dancing together well } \\
\partial \text { Drawing and coloring the picture }\end{array}$ & & & \\
\hline \multirow[t]{5}{*}{ My family } & Cognitive & $\begin{array}{l}\partial \text { Understanding the concept of } \\
\text { family tree } \\
\partial \text { Mentioning their family member } \\
\text { correctly } \\
\partial \text { Matching the photograph with } \\
\text { the family member }\end{array}$ & \multirow[t]{4}{*}{4 weeks } & \multirow{4}{*}{$\begin{array}{l}\text { Drawing the } \\
\text { family tree } \\
\partial \text { Drilling the } \\
\text { vocabulary } \\
\text { related to } \\
\text { family member } \\
\partial \text { Matching } \\
\text { words with the } \\
\text { pictures which } \\
\text { describe } \\
\text { family member } \\
\partial \text { Explaining the } \\
\text { family member } \\
\partial \text { Playing games }\end{array}$} & \multirow{4}{*}{$\begin{array}{l}\partial \text { Drawing the } \\
\text { family tree } \\
\partial \text { Mentioning the } \\
\text { family member } \\
\partial \text { Matching the } \\
\text { words with the } \\
\text { pictures } \\
\partial \text { Writing down the } \\
\text { family member } \\
\text { correctly } \\
\partial \text { Describing the } \\
\text { family member } \\
\text { correctly }\end{array}$} \\
\hline & $\begin{array}{l}\text { Language } \\
\text { and Literacy }\end{array}$ & $\begin{array}{l}\partial \text { Talking about their family life } \\
\partial \text { Mentioning their family name } \\
\partial \text { Answering the questions from } \\
\text { teacher } \\
\partial \text { Writing family member } \\
\text { correctly }\end{array}$ & & & \\
\hline & $\begin{array}{l}\text { Socio- } \\
\text { Emotional }\end{array}$ & $\begin{array}{l}\partial \text { Working in groups well } \\
\partial \text { Sharing the toys with other } \\
\text { friends }\end{array}$ & & & \\
\hline & $\begin{array}{l}\text { Motoric/phys } \\
\text { ics }\end{array}$ & $\begin{array}{l}\partial \text { Moving their body based on the } \\
\text { instruction } \\
\partial \text { Coloring the picture based on } \\
\text { the instruction } \\
\partial \text { Dancing based on the video well }\end{array}$ & & & \\
\hline & Cognitive & $\begin{array}{l}\partial \text { Mentioning the name of wild } \\
\text { animals, tame animals, and pets } \\
\partial \text { Mentioning their pets at home } \\
\partial \text { Classifying the animals into pets } \\
\text { and wild animals }\end{array}$ & & $\begin{array}{l}\partial \text { Introducing } \\
\text { kinds of } \\
\text { animals } \\
\partial \text { Explaining the } \\
\text { characteristics }\end{array}$ & $\begin{array}{ll}\partial \text { Mentioning } \\
\text { kinds of animals } \\
\partial \text { Writing down the } \\
\text { words of animals } \\
\partial \text { Drawing the }\end{array}$ \\
\hline
\end{tabular}




\begin{tabular}{|c|c|c|c|c|c|}
\hline \multirow[t]{3}{*}{ Animals } & $\begin{array}{l}\text { Language } \\
\text { and Literacy }\end{array}$ & $\begin{array}{l}\partial \text { Writing the name of animals } \\
\partial \text { Describing the characteristics of } \\
\text { wild animals, tame animals, and } \\
\text { pets } \\
\partial \text { Spelling the words well } \\
\partial \text { Asking the questions } \\
\partial \text { Producing the sounds of the } \\
\text { animals }\end{array}$ & \multirow[t]{3}{*}{4 weeks } & \multirow[t]{3}{*}{$\begin{array}{l}\text { of animals } \\
\partial \text { Spelling the } \\
\text { words } \\
\partial \text { Matching the } \\
\text { words with the } \\
\text { picture } \\
\partial \text { Listening to } \\
\text { the video about } \\
\text { the animal } \\
\text { sounds }\end{array}$} & \multirow[t]{3}{*}{$\begin{array}{l}\text { animals on the } \\
\text { drawing book } \\
\partial \text { Matching the } \\
\text { words with the } \\
\text { pictures } \\
\partial \text { Mentioning and } \\
\text { distinguishing } \\
\text { the animal } \\
\text { sounds correctly }\end{array}$} \\
\hline & $\begin{array}{l}\text { Socio- } \\
\text { emotional }\end{array}$ & $\begin{array}{l}\partial \text { Working in groups well } \\
\partial \text { Showing their interest in playing } \\
\text { the games } \\
\partial \text { Sharing their toys to others } \\
\partial \text { Borrowing their colored pencil } \\
\text { to other friends }\end{array}$ & & & \\
\hline & $\begin{array}{l}\text { Motoric/phys } \\
\text { ics }\end{array}$ & $\begin{array}{l}\partial \text { Moving their body well based on } \\
\text { the instruction from teacher } \\
\partial \text { Imitating teachers' movement in } \\
\text { playing games } \\
\partial \text { Arranging the puzzle well } \\
\partial \text { drawing and coloring the picture } \\
\text { well }\end{array}$ & & & \\
\hline \multirow[t]{4}{*}{ Vegetables } & Cognitive & $\begin{array}{l}\partial \text { Mentioning kinds of vegetables } \\
\partial \text { Describing the color of certain } \\
\text { vegetables } \\
\partial \text { Describing the characteristics of } \\
\text { the vegetables } \\
\partial \text { Classifying the vegetables }\end{array}$ & \multirow[t]{3}{*}{3 weeks } & \multirow{3}{*}{$\begin{array}{l}\partial \text { Introducing the } \\
\text { plants } \\
\text { (vegetables, } \\
\text { fruits, and } \\
\text { flowers) } \\
\partial \text { Spelling the } \\
\text { words } \\
\partial \text { Matching the } \\
\text { words with } \\
\text { pictures } \\
\partial\end{array}$} & \multirow{3}{*}{$\begin{array}{l}\partial \text { Matching the } \\
\text { words with the } \\
\text { pictures } \\
\partial \text { Coloring the } \\
\text { pictures } \\
\partial \text { Spelling the } \\
\text { words correctly } \\
\partial \text { Writing down the } \\
\text { words correctly }\end{array}$} \\
\hline & $\begin{array}{l}\text { Language } \\
\text { and Literacy }\end{array}$ & $\begin{array}{l}\partial \text { Spelling the words correctly } \\
\partial \text { Answering the questions from } \\
\text { teacher } \\
\partial \text { Writing the name of vegetables } \\
\partial \text { Asking the questions to teacher } \\
\partial \text { Responding to teacher's } \\
\text { instruction }\end{array}$ & & & \\
\hline & $\begin{array}{l}\text { Socio- } \\
\text { Emotional }\end{array}$ & $\begin{array}{l}\partial \text { Showing sympathy to others } \\
\partial \text { Engaging in independent play } \\
\partial \text { Engaging in social play }\end{array}$ & & & \\
\hline & $\begin{array}{l}\text { Motoric/phys } \\
\text { ics }\end{array}$ & $\begin{array}{l}\partial \text { Planting the seeds of the plant } \\
\partial \text { Coloring the picture well } \\
\partial \text { Cutting the picture and putting it } \\
\text { on the wall }\end{array}$ & & & \\
\hline
\end{tabular}




\section{SYLLABUS \\ EVEN SEMESTER}

Class $\quad:$ TK B

Standard Competence $\quad$ : Students are able to understand simple vocabulary and to respond the simple instruction correctly at fun activities

\begin{tabular}{|c|c|c|c|c|c|}
\hline Theme & Indicator & $\begin{array}{c}\text { Time } \\
\text { Allotment }\end{array}$ & Materials & Media & Evaluation \\
\hline $\begin{array}{l}\text { Transportation } \\
\text { vehicle }\end{array}$ & 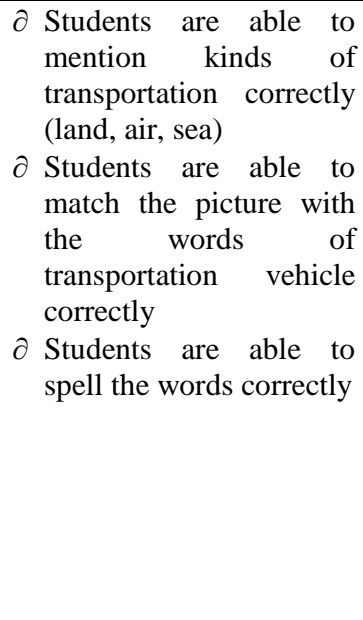 & 4 weeks & $\begin{array}{l}\partial \text { Introducing the } \\
\text { transportation } \\
\text { vehicle } \\
\partial \text { Drilling the } \\
\text { name of } \\
\text { transportation } \\
\text { vehicle } \\
\partial \text { Drawing the } \\
\text { picture based } \\
\text { on the given } \\
\text { instruction } \\
\partial \text { Singing the } \\
\text { song "The } \\
\text { wheels on the } \\
\text { bus" and } \\
\text { "London bridge } \\
\text { is falling down" }\end{array}$ & $\begin{array}{ll}\partial & \text { Picture } \\
\partial & \text { Tape } \\
& \text { Recorder } \\
\partial & \text { Whiteboard } \\
\partial & \text { Marker } \\
\partial & \text { Drawing } \\
\text { book } \\
\partial \text { Color pencil } \\
\partial\end{array}$ & $\begin{array}{l}\partial \text { Matching the } \\
\text { picture with } \\
\text { the parts of } \\
\text { body } \\
\partial \text { Writing the } \\
\text { words of } \\
\text { transportation } \\
\text { vehicle } \\
\text { correctly }\end{array}$ \\
\hline Occupation & $\begin{array}{l}\partial \text { Students are able to } \\
\text { mention kinds of } \\
\text { occupation correctly } \\
\partial \text { Students are able to } \\
\text { mention their parents' } \\
\text { occupation } \\
\partial \text { Students are able to } \\
\text { spell the words correctly } \\
\partial \text { Students are able to } \\
\text { match the words and the } \\
\text { pictures correctly } \\
\partial \text { Students are able to act } \\
\text { in the role play } \\
\partial \text { Students are able to } \\
\text { write down the name of } \\
\text { the occupation well }\end{array}$ & 4 weeks & $\begin{array}{l}\partial \text { Introducing } \\
\text { kinds of } \\
\text { occupation } \\
\partial \text { Drilling the } \\
\text { name of the } \\
\text { occupation } \\
\partial \text { Matching the } \\
\text { picture with the } \\
\text { words } \\
\partial \text { Coloring the } \\
\text { pictures } \\
\partial \text { Acting on the } \\
\text { role play }\end{array}$ & $\begin{array}{l}\partial \text { Realia } \\
\partial \text { Picture } \\
\partial \text { Drawing } \\
\text { book } \\
\partial \text { Color pencil }\end{array}$ & $\begin{array}{l}\partial \text { Mentioning } \\
\text { the name of } \\
\text { occupation } \\
\partial \text { Writing down } \\
\text { the kinds of } \\
\text { occupation } \\
\partial \text { Matching the } \\
\text { picture with } \\
\text { the words } \\
\partial \text { Spelling the } \\
\text { words } \\
\text { correctly }\end{array}$ \\
\hline $\begin{array}{l}\text { Communication } \\
\text { tools }\end{array}$ & $\begin{array}{l}\partial \text { Students are able to } \\
\text { mention communication } \\
\text { tools correctly } \\
\partial \text { Students are able to } \\
\text { spell the words correctly } \\
\partial \text { Students are able to } \\
\text { respond the simple } \\
\text { instruction } \\
\partial \text { Students are able to } \\
\text { write down kinds of } \\
\text { occupation well }\end{array}$ & 3 weeks & $\begin{array}{l}\partial \text { Introducing the } \\
\text { communication } \\
\text { tools } \\
\partial \text { Describing the } \\
\text { communication } \\
\text { tools } \\
\partial \text { Spelling the } \\
\text { words } \\
\partial \text { Coloring the } \\
\text { pictures }\end{array}$ & $\begin{array}{l}\partial \text { Realia } \\
\partial \text { Pictures } \\
\partial \text { Drawing } \\
\text { book } \\
\partial \text { Color pencil } \\
\partial \text { Whiteboard } \\
\partial \text { Marker }\end{array}$ & $\begin{array}{l}\partial \text { Spelling the } \\
\text { words } \\
\text { correctly } \\
\partial \text { Matching the } \\
\text { pictures with } \\
\text { the words } \\
\partial \text { Writing down } \\
\text { the name of } \\
\text { communicatio } \\
\mathrm{n} \text { tools } \\
\text { correctly }\end{array}$ \\
\hline
\end{tabular}

